\title{
The use of various strains of Rhizobium tropici for inoculation of snap bean cultivars with a determinate growth pattern
}

\section{Inoculação com estirpes de Rhizobium tropici em genótipos de feijão- vagem de crescimento determinado}

\author{
Felipe Favoretto Furlan ${ }^{1 *}$; Gustavo Henrique Freiria ${ }^{1}$; Guilherme Augusto Cito \\ Alves $^{1}$; Guilherme Renato Gomes ${ }^{1}$; Luiz Henrique Campos de Almeida ${ }^{1}$; \\ Mateus Favoretto Furlan²; Lúcia Sadayo Assari Takahashi ${ }^{3}$
}

\begin{abstract}
The snap bean (Phaseolus vulgaris L.) is an economically important vegetable in Brazil. Bean plants can establish symbiotic associations with bacteria that fix atmospheric nitrogen. These associations show specificity of host plants to certain bacteria. Nitrogen fertilization constitutes a crop production cost, and the use of Rhizobium inoculation to supply nitrogen to crops may decrease the production costs. The aim of this study was to evaluate the effects of inoculation of three different snap bean cultivars with three Rhizobium tropici strains on agronomical performance of the plant. A completely randomized experimental design was used, with a $3 \times 5$ factorial scheme and four replicates per treatment. The factors tested were three snap bean cultivars (UEL 1, Alessa, and UEL 2), and five types of inoculation (uninoculated control, inoculation with SEMIA 4077, SEMIA 4080, SEMIA 4088, or with a mix of the three strains). The experiment was conducted in a greenhouse. Plant height, stem diameter, pod length, the number of pods per plant, and average weight and yield of commercial-grade pods, were determined. An analysis of variance was conducted using the $\mathrm{F}$ test, followed by Tukey's test ( $\mathrm{p}<$ 0.05). Inoculation had a positive effect on all the parameters quantified. The beneficial effect was more pronounced in plants inoculated with the mix of Rhizobium strains.
\end{abstract}

Key words: Inoculant. Nitrogen. Phaseolus vulgaris L.

\section{Resumo}

O feijão-vagem (Phaseolus vulgaris L.) é uma hortaliça destaque no mercado nacional. O feijoeiro tem a habilidade de associar-se simbioticamente com bactérias responsáveis pela fixação biológica do nitrogênio, sendo observada neste processo a especificidade entre genótipo e bactéria. A adubação nitrogenada constitui parte dos custos de produção, os quais podem ser reduzidos pelo uso da inoculação para fornecimento de $\mathrm{N}$ à cultura. $\mathrm{O}$ objetivo desse trabalho foi avaliar o desempenho agronômico de três genótipos de feijão-vagem inoculados com três estirpes de Rhizobium tropici. O delineamento experimental foi inteiramente casualizado com quatro repetições, conduzido em casa de vegetação, resultando em fatorial 3x5: três genótipos (UEL 1, Alessa e UEL 2) e cinco condições de inoculação (testemunha sem inoculação, SEMIA 4077, SEMIA 4080, SEMIA 4088 e a mistura dos três isolados). Foram avaliados altura da planta, diâmetro do colmo, comprimento de vagens, número de vagens por

\footnotetext{
${ }^{1}$ Discentes do Curso de Doutorado do Programa de Pós-Graduação em Agronomia, Departamento de Agronomia, Universidade Estadual de Londrina, UEL, Londrina, PR, Brasil. E-mail: ffavorettofurlan@gmail.com; gustavo-freiria@hotmail.com; guilhermecito@hotmail.com; guigomes88@hotmail.com; caluizhenrique@msn.com

2 Discente do Curso de Agronomia, Universidade do Norte do Paraná, UNOPAR, Londrina, PR, Brasil. E-mail: mateus_09_02@ hotmail.com

${ }^{3}$ Prof $^{\mathrm{a}} \mathrm{Dr}^{\mathrm{a}}$, Departamento de Agronomia, UEL, Londrina, PR, Brasil. E-mail: sadayo@uel.br

* Author for correspondence
} 
planta, peso médio de vagens comerciais e produtividade. Os resultados foram submetidos à análise de variância pelo teste $\mathrm{F}(\mathrm{p}<0,05)$ e as médias comparadas pelo teste de Tukey $(\mathrm{p}<0,05)$. Todas as variáveis responderam positivamente à inoculação, sendo que a mistura de estirpes mostrou-se mais promissora.

Palavras-chave: Inoculantes. Nitrogênio. Phaseolus vulgaris L.

\section{Introduction}

The snap bean, Phaseolus vulgaris L., is a leguminous plant originating from Central America (PINTO et al., 2007). It is one of the most consumed plants in Brazil, and its average production for the 2010 harvest was approximately 57 thousand tons (CEASA, 2010).

Because it is consumed without processing, its marketing standards include both morphological and physiological pod quality. In order to meet these standards, the plants must be supplied with adequate amounts of nutrients during cultivation because a deficient nutrient supply disrupts metabolic pathways, with detrimental effects on the plant (FAGERIA et al., 1996). Nitrogen (N) is the nutrient required in greater amounts by plants (GALLO; MIYASAKA, 1961) and should be supplied in adequate quantity, especially during flowering and pod formation and filling stages (ARF et al., 1999).

The appropriate management of $\mathrm{N}$ provision to plants is therefore a challenge for the bean industry because low $\mathrm{N}$ availability limits bean production, but excess $\mathrm{N}$ supply exceedingly increases production costs, in addition to posing environmental risks due to nitrate leaching and surface N runoff (SANTOS et al., 2003). Gaseous $\mathrm{N}$ losses due to denitrification and volatilization should also be considered (SIQUEIRA et al., 1994).

Bean plants form symbiotic associations with bacteria from the genus Rhizobium, which fix atmospheric $\mathrm{N}$ in root nodules. In some cases, this association may have low efficiency, insufficient to meet the host plant's N demand (GUARESCHI; PERIN, 2009). Nonetheless, depending on the growth conditions, the above approach can partially or completely replace $\mathrm{N}$ fertilization, thereby decreasing production costs (GRANGE et al., 2007).

Symbiotic N fixation in bean plants can be optimized through selection of more efficient Rhizobium strains, adapted to different regions and bean cultivars. Several factors affect the efficiency of the association, namely the ability of the inoculated Rhizobium strains to colonize the host plant; this phenomenon is due to symbiotic specificity and varies with the strain and the host plant (SMITH; GOODMAN, 1999).

Root colonization by a particular inoculated Rhizobium strain probably involves several phases of nodule formation, which can result in competition between different strains for nodule occupation and promote nodule development (SESSITSCH et al., 2002).

The aim of the present study was to evaluate the effects of inoculation of seeds of three snap bean cultivars (with a determinate growth pattern) with different strains of Rhizobium tropici. These effects were assessed by means of phytometric and plant yield parameters.

\section{Materials and Methods}

The experiment was performed in a greenhouse in the Department of Agronomy of the Agrarian Sciences Research Center of the Universidade Estadual de Londrina (UEL), located at $23^{\circ} 19^{\prime} 42^{\prime \prime}$, $51^{\circ} 12^{\prime} 11^{\prime \prime} \mathrm{W}$ and altitude $594 \mathrm{~m}$.

Soil samples were collected from the superficial soil layer $(0-20 \mathrm{~cm})$ of a Red Latosol, in the experimental area of the School Farm of UEL, and were placed in 4-L plastic pots. Before sowing, the soil samples were sifted (pore diameter $4.0 \mathrm{~mm}$ ), 
and chemical analysis of the soil was performed, in order to determine soil fertility (PAVAN et al., 1992). The soil had the following characteristics: $\mathrm{pH} 5.6$ (resulting from $\mathrm{CaCl}_{2}$ ); $23.2 \mathrm{~g} \mathrm{~kg}^{-1}$ organic matter, $0.35 \mathrm{mg} \mathrm{dm}^{-3} \mathrm{P} ; 896 \mathrm{mg} \mathrm{dm}^{-3} \mathrm{~K} ; 6.2 \mathrm{cmloc} \mathrm{dm}^{-3} \mathrm{Ca}$; $2.2 \mathrm{cmloc} \mathrm{dm}^{-3} \mathrm{Mg} ; 4.85 \mathrm{cmloc} \mathrm{dm}^{-3} \mathrm{H}+\mathrm{Al}$; CTC: $15.5 \mathrm{cmloc} \mathrm{dm}^{-3}$; V: $68.8 \%$.

The soil was corrected on the basis of the chemical analysis, with application of urea at 15 $\mathrm{kg} \mathrm{ha}^{-1}$ (corresponding to a half dose of $\mathrm{N}$ ), 70 $\mathrm{kg} \mathrm{ha}{ }^{-1} \mathrm{P}_{2} \mathrm{O}_{5}$, and $40 \mathrm{~kg} \mathrm{ha}{ }^{-1} \mathrm{~K}_{2} \mathrm{O}$ (OLIVEIRA, 2003). A nutrient solution was applied in order to avoid nutrient limitation, according to Novais et al. (1991).

Throughout the experiment, the soil water content in the pots was maintained at $70 \%$ of field capacity by daily replacement of the water lost through evapotranspiration.

Seeds of snap bean cultivars UEL-1, UEL-2, and Alessa, with a determinate growth pattern, were used. Inocula of Rhizobium strains SEMIA 4077, SEMIA 4080, and SEMIA 4088, at $10^{5}$ cells $\mathrm{mL}^{-1}$, were produced in the laboratory. The strain mix was prepared by mixing $5 \mathrm{~mL}$ of each strain. Inoculation was performed at sowing, by applying $5 \mathrm{~mL}$ of the inoculum of a pure culture or strain mix. Three seeds were sown per pot, and thinned to one seedling per pot 15 days after seedling emergence.

The following parameters were determined: plant height $(\mathrm{H})$, stem diameter (SD), shoot dry weight
(SDW), the number of commercial-grade pods (NCP), length of commercial-grade pods (LCP), average pod weight (APW), and pod yield (Y). The $\mathrm{H}$ value was measured at the base of the plant up to the insertion of the last trifoliate leaf in the main stem. NCP was quantified by counting all pods longer than $10 \mathrm{~cm}$. The pod yield was calculated using the equation $\mathrm{Y}(\mathrm{x})=$ Number of plants * NCP * APW[per 1000] $\div 1000$, and expressed in tons (FANCELLI; DOURADO NETO, 2007).

A completely randomized experimental design was used, with a $3 \times 5$ factorial scheme and four replicates per treatment. The tested factors were three snap bean cultivars (1: UEL 1, 2: Alessa, and 3: UEL 2) and five types of inoculation (1: uninoculated control, 2: strain SEMIA 4077, 3: strain SEMIA 4080, 4: strain SEMIA 4088, 5: strain mix).

An analysis of variance was conducted using the F test, followed by Tukey's test, at $\mathrm{p} \leq 0.05$.

\section{Results and Discussion}

No significant interactions between the bean cultivar and inoculation were observed for SDW and LCP, but there was a significant of isolated effect on both parameters (Table 1). The significant effect of the bean cultivar was due to genetic differences among the cultivars. Nonetheless, the responses to the different types of inoculation were independent of the host plant genotype.

Table 1. Simplified analysis of variance for the parameters under study.

\begin{tabular}{cccccccc}
\hline \multirow{2}{*}{ Variation sources } & \multicolumn{5}{c}{ Mean Square } \\
\cline { 2 - 7 } & $\mathrm{H}^{1}$ & $\mathrm{SD}^{2}$ & $\mathrm{SDW}^{3}$ & $\mathrm{NCP}^{4}$ & $\mathrm{LCP}^{5}$ & $\mathrm{APW}^{6}$ & $\mathrm{Y}^{7}$ \\
\hline Cultivar $(\mathrm{G})$ & $158.04^{* *}$ & $0.05^{* *}$ & $2.93^{* *}$ & $13.52^{* *}$ & $1.13^{*}$ & $0.98^{* *}$ & $4.85^{* *}$ \\
Inoculation $(\mathrm{I})$ & $123.04^{* *}$ & $0.21^{* *}$ & $6.39^{* *}$ & $96.92^{* *}$ & $24.43^{* *}$ & $0.70^{* *}$ & $61.10^{* *}$ \\
$\mathrm{G} \times \mathrm{I}$ & $5.71^{* *}$ & $0.01^{*}$ & $0.15^{\mathrm{ns}}$ & $5.33^{*}$ & $0.64^{\mathrm{ns}}$ & $0.45^{* *}$ & $2.70^{* *}$ \\
\hline C.V. $(\%)$ & 4.24 & 6.73 & 9.20 & 12.64 & 4.47 & 5.28 & 11.36 \\
\hline
\end{tabular}

*Significant at $\mathrm{p} \leq 0.05, * *$ significant at $\mathrm{p} \leq 0.01$, and ${ }^{\mathrm{ns}}$ non significant, according to the $\mathrm{F}$ test.

${ }^{1} \mathrm{H}$ : plant height; ${ }^{2} \mathrm{SD}$ : stem diameter; ${ }^{3} \mathrm{SDW}$ : shoot dry weight; ${ }^{4} \mathrm{NCP}$ : the number of commercial-grade pods; ${ }^{5} \mathrm{LCP}:$ length of commercial-grade pods; ${ }^{6} \mathrm{APW}$ : average pod weight; and ${ }^{7} \mathrm{Y}$ : pod yield. 
The inoculated plants yielded higher SDW than control plants did, regardless of whether the bacterial strains were inoculated alone or as a mix. This result was likely due to a higher $\mathrm{N}$ concentration in the plants, resulting in increased production of photoassimilates and in plant growth (LONG et al., 2006). Higher production of plant mass in inoculated plants has been reported previously (GUEDES et al., 2010; SOARES et al., 2006).

The inoculated plants yielded greater LCP than the control plants (Table 1), thus producing commercial-grade pods (longer than $10 \mathrm{~cm}$ ). This finding is in agreement with the data of Nóbrega et al. (2010) and confirms a positive effect of Rhizobium inoculation on the host plants.

Inoculation had a positive effect on $\mathrm{H}$, with inoculated plants showing higher $\mathrm{H}$ than uninoculated controls did (Table 2). This is because the symbiotic association can results in increased photosynthetic rates and root activity, increasing nodulation; the observed phenomenon is in line with the data from Gualter et al. (2008), who observed increased higher plant size after colonization.

Table 2. Plant height $(\mathrm{H})$ and stem diameter (SD) in plants of different snap bean cultivars, inoculated with different strains of Rhizobium tropici.

\begin{tabular}{cccccc}
\hline \multirow{2}{*}{ Cultivar } & \multicolumn{5}{c}{ Rhizobium strain } \\
\cline { 2 - 5 } & Control & SEMIA 4077 & SEMIA 4080 & SEMIA 4088 & Mix \\
\cline { 2 - 5 } UEL 1 & $26.60 \mathrm{Ad}$ & $32.40 \mathrm{Abc}$ & $30.43 \mathrm{Ac}$ & $32.95 \mathrm{Ab}$ & $37.18 \mathrm{Aa}$ \\
Alessa & $23.68 \mathrm{Bc}$ & $27.68 \mathrm{Bb}$ & $26.68 \mathrm{Bb}$ & $26.65 \mathrm{Bb}$ & $30.20 \mathrm{Ca}$ \\
UEL 2 & $22.83 \mathrm{Bc}$ & $26.25 \mathrm{Bb}$ & $27.68 \mathrm{Bb}$ & $26.00 \mathrm{Bb}$ & $32.80 \mathrm{Ba}$ \\
\cline { 2 - 6 } & & \multicolumn{5}{c}{ Stem diameter $\mathbf{( c m )}$} \\
UEL 1 & $0.85 \mathrm{Ac}$ & $1.03 \mathrm{Ab}$ & $0.99 \mathrm{Abc}$ & $1.09 \mathrm{Ab}$ & $1.35 \mathrm{Aa}$ \\
Alessa & $0.88 \mathrm{Ac}$ & $1.04 \mathrm{Ab}$ & $1.04 \mathrm{Ab}$ & $1.01 \mathrm{Abc}$ & $1.21 \mathrm{Ba}$ \\
UEL 2 & $0.80 \mathrm{Ab}$ & $0.98 \mathrm{Aa}$ & $0.96 \mathrm{Aa}$ & $1.01 \mathrm{Aa}$ & $1.09 \mathrm{Ca}$ \\
\hline
\end{tabular}

Averages followed by different lowercase letters within the same row, and uppercase letters within the same column, were significantly different according to Tukey's test, at $\mathrm{p} \leq 0.05$.

Inoculation resulted in increased $\mathrm{H}$ and $\mathrm{SD}$. These effects were more pronounced for cultivar UEL 1, and for inoculation with the strain mix, and to a lesser extent for strain SEMIA 4088 (Table 2). The possible reason is different colonization rates, which vary among the different Rhizobium-host plant combinations, indicating symbiotic specificity (PAFFETTI et al., 1998). The wider the host range, the lower the specificity of a given Rhizobium isolate (BORGES et al., 2007).

According to the above-mentioned parameters, plants inoculated with the three tested Rhizobium strains showed better agronomical properties than the uninoculated controls, independent of the plant cultivar (Table 3).
Optimization of $\mathrm{N}$ fixation depends on increased nodule activity and may explain the effects on the parameters measured. The host plant supplies carbohydrates originating from photosynthesis to the rhizobial bacteria, and in exchange receives $\mathrm{N}$ fixed by the bacteria (STRALIOTTO, 2002). This situation results in higher $\mathrm{N}$ uptake by the host plant.

Overall, cultivar Alessa yielded the highest NCP, regardless of treatment. Treatments 4 and 5 had similar effects on NCP for all plant cultivars. This result is consistent with the findings of Barros et al. (2013), who observed a greater number of pods per plant among inoculated plants. 
Table 3. The number of commercial-grade pods (NCP), pod average weight (APW), and pod yield (Y) in plants of different snap bean cultivars, inoculated with different strains of Rhizobium tropici.

\begin{tabular}{cccccc}
\hline & \multicolumn{5}{c}{ Rhizobium strain } \\
Cultivar & Control & SEMIA 4077 & SEMIA 4080 & SEMIA 4088 & Mix \\
\cline { 2 - 6 } UEL 1 & \multicolumn{5}{c}{ Number of commercial grade pods } \\
Alessa & $8.25 \mathrm{Ac}$ & $10.00 \mathrm{Bbc}$ & $11.50 \mathrm{Bb}$ & $11.50 \mathrm{Ab}$ & $15.50 \mathrm{Aa}$ \\
UEL 2 & $7.00 \mathrm{Ac}$ & $13.50 \mathrm{Ab}$ & $14.25 \mathrm{Aab}$ & $11.75 \mathrm{Ab}$ & $16.50 \mathrm{Aa}$ \\
& $7.00 \mathrm{Ac}$ & $10.25 \mathrm{Bb}$ & $11.50 \mathrm{Bab}$ & $12.50 \mathrm{Aab}$ & $14.00 \mathrm{Aa}$ \\
\cline { 2 - 6 } UEL 1 & $4.78 \mathrm{Aab}$ & $5.27 \mathrm{Aa}$ Average pod weight (g) \\
Alessa & $4.53 \mathrm{Ab}$ & $5.15 \mathrm{Aa}$ & $4.88 \mathrm{Bab}$ & $4.63 \mathrm{Bb}$ & $4.87 \mathrm{Bab}$ \\
UEL 2 & $4.59 \mathrm{Ac}$ & $5.15 \mathrm{Ab}$ & $5.84 \mathrm{Aa}$ & $5.10 \mathrm{Abc}$ & $5.74 \mathrm{Aa}$ \\
\cline { 2 - 6 } & & \multicolumn{5}{c}{ Pod yield (t ha $\left.\mathbf{~}^{-1}\right)$} \\
UEL 1 & $5.51 \mathrm{Ac}$ & $7.37 \mathrm{Bbc}$ & $7.84 \mathrm{Bb}$ & $7.44 \mathrm{Ab}$ & $10.52 \mathrm{Aa}$ \\
Alessa & $4.36 \mathrm{Ac}$ & $9.72 \mathrm{Aab}$ & $9.50 \mathrm{Ab}$ & $8.54 \mathrm{Ab}$ & $11.47 \mathrm{Aa}$ \\
UEL 2 & $4.47 \mathrm{Ad}$ & $7.42 \mathrm{Bc}$ & $9.40 \mathrm{ABab}$ & $8.93 \mathrm{Abc}$ & $11.20 \mathrm{Aa}$ \\
\hline
\end{tabular}

Averages followed by different lowercase letters within the same row, and uppercase letters within the same column, were significantly different according to Tukey's test, at $\mathrm{p} \leq 0.05$.

The fact that no statistically significant differences in NCP were observed among the plants inoculated with some of the isolated strains and the strain mix or the control treatment (Table 3) indicates symbiotic specificity. This was the case for UEL 1 with treatments 1 and 2, for which no significant increase in NCP was observed when compared to control plants. Bassan et al. (2001) did not observe higher NCP in inoculated plants either.

APW was significantly higher for inoculated plats, except for UEL 1, for which no significant differences were observed among most of the treatments tested (Table 3 ). For the other cultivars tested, inoculation with the strain mix had a more pronounced positive effect on APW than the remaining treatments did, as was reported elsewhere about the parameters discussed above (XAVIER et al., 2006). This phenomenon was likely due to a higher $\mathrm{N}$ fixation activity because of the joint action of the three Rhizobium strains.

The remaining variations observed resulted from the already discussed symbiotic specificity. Almeida et al. (2010) also reported a positive effect of inoculation.
The highest pod yield was observed for treatment 5. Nonetheless, pod yield was higher for all inoculation treatments than for the control treatment (Table 3). Pod yield was higher for cultivar Alessa because, although some plants had lower pod weight than UEL 2, they produced a greater number of pods.

Yadegari et al. (2010) observed a significant effect of Rhizobium inoculation combined with plant growth-promoting bacteria in bean plants, resulting in higher yield parameters, namely NCP and yield. Higher plant yields resulting from Rhizobium inoculation have also been reported in other studies (PERES et al., 1994; ROMANINI JÚNIOR et al., 2007; GITTI et al., 2012). All the parameters measured manifested the same behavior in response to inoculation, confirming beneficial effects of the Rhizobium inoculation.

\section{Conclusion}

Inoculation had a beneficial effect on bean plants and can replace, partly, $\mathrm{N}$ fertilization with chemical fertilizers. All the bean cultivars tested showed 
positive responses to Rhizobium inoculation. The tested Rhizobium strains increased the yield parameters of the bean plant, especially when combined in a mix, which had more pronounced positive effects than did the bacterial strains applied alone.

\section{Acknowledgements}

The authors are grateful to the the CAPES (Coordination for the Improvement of Higher Education Personnel), CNPq (Brazilian National Council for Scientific and Technological Development) and Araucária Foundation for financial support.

\section{References}

ALMEIDA, A. L. G.; ALCÂNTARA, R. M. C. M.; NÓBREGA, R. S. A.; NÓBREGA, J. C. A.; LEITE, L. F. C.; SILVA, J. A. L. Produtividade do feijão-caupi cv BR 17 Gurguéia inoculado com bactérias diazotróficas simbióticas no Piauí. Revista Brasileira de Ciências Agrárias, Recife, v. 5, n. 3, p. 364-369, 2010.

ARF, O.; FERREIRA, E. C.; CARVALHO, M. A. C.; SÁ, M. E.; BUZETTI, S. Efeito de doses e parcelamento da adubação nitrogenada em cobertura na cultura do feijão. In: REUNIÃ̃ NACIONAL DE PESQUISA DE FEIJÃO, 6., 1999, Salvador. Anais... Goiânia: Embrapa, 1999. p. 790-793.

BARROS, R. L. N.; OLIVEIRA, L. B.; MAGALHÃES, W. B.; MÉDICI, L. O.; PIMENTEL, C. Interação entre inoculação com rizóbio e adubação nitrogenada de plantio na produtividade do feijoeiro nas épocas da seca e das águas. Semina: Ciências Agrárias, Londrina, v. 34, n. 4, p. 1443-1450, 2013.

BASSAN, D. A. Z.; ARF, O.; BUZETTI, S.; CARVALHO, M. A. C.; SANTOS, N. C. B.; SÁ, M. E. Inoculação de sementes e aplicação de nitrogênio e molibdênio na cultura do feijão de inverno: produção e qualidade fisiológica de sementes. Revista Brasileira de Sementes, Brasília, v. 23, n. 1, p. 76-83, 2001.

BORGES, W. L.; NEVES, M. C.; RUNJANEK, N. G.; NASCIMENTO, L. R. Faixa hospedeira de rizóbios isolados das espécies Arachis hypogaea, Stylosanthes guyanensis e Aeschynomene americana. Revista Brasileira de Ciências Agrárias, Recife, v. 2, n. 1, p. 2027, 2007.
CENTRAIS ESTADUAIS DE ABASTECIMENTO CEASA. Prohort - Programa Brasileiro de Modernização do Mercado de Hortigranjeiro. Brasília: Companhia Nacional de Abastecimento, CONAB, 2010. Disponível em: $<$ http://www.ceasa.gov.br/precos.php $>$. Acesso em: 07 set. 2015.

FAGERIA, N. K.; OLIVEIRA, I. P.; DUTRA, L. G. Deficiências nutricionais na cultura do feijoeiro e suas correções. Goiânia: EMBRAPA-Cnpaf, 1996. 40 p. (Documentos, 65).

FANCELLI, A. L.; DOURADO NETO, D. Produção de feijão. Piracicaba: ESALQ/USP, 2007. 386 p.

GALLO, J. R.; MIYASAKA, S. Composição química do feijoeiro e absorção de elementos nutritivos, do florescimento à floração. Bragantia, Campinas, v. 20, n. 40, p. 867-884, 1961.

GITTI, D. C.; ARF, O.; KANEKO, F. H.; RODRIGUES, R. A. F.; BUZETTI, S.; PORTUGAL, J. R.; CORSINI, D. C. D. C. Inoculação de Azospirillum brasilense em cultivares de feijões cultivados no inverno. Agrarian, Dourados, v. 5, n. 15, p. 36-46, 2012.

GRANGE, L.; HUNGRIA, M.; GRAHAM, P. H.; MARTÍNEZ-ROMERO, E. New insights into the origins and evolution of rhizobia that nodulate common bean (Phaseolus vulgaris) in Brazil. Soil Biology \& Biochemistry, Brisbaine, v. 39, n. 4, p. 867-876, 2007.

GUALTER, R. M. R.; LEITE, L. F. C.; ARAUJO, A. S. F.; ALCANTARA, R. M. C. M.; COSTA, D. B. Inoculação e adubação mineral em feijão Caupi: efeitos na nodulação, crescimento e produtividade. Scientia Agraria, Curitiba, v. 9, n. 4, p. 469-474, 2008.

GUARESCHI, R. F.; PERIN, A. Efeito do molibdênio nas culturas da soja e do feijão via adubação foliar. Global Science and Technology, Rio Verde, v. 2, n. 3, p. 8-15, 2009.

GUEDES, G. N.; SANTOS SOUZA, A. dos; LIMA, A. S.; SOUSA ALVES, L. de. Eficiência agronômica de inoculantes em feijão-caupi no município de Pombal PB. Revista Verde de Agroecologia e Desenvolvimento Sustentável, Pombal, v. 5, n. 4, p. 82-89, 2010.

LONG, S. P.; ZHU, X. Z.; NAIDU, S. L.; ORT, D. Can improvement in photosynthesis increase crop yields? Plant, Cell and Environment, Malden, v. 29, n. 3, p. 315330, 2006.

NÓBREGA, J. C. A.; LEITE, L. F. C.; SILVA, J. A. L. da. Produtividade do feijão-caupi cv BR 17 Gurguéia inoculado com bactérias diazotróficas simbióticas no Piauí. Revista Brasileira de Ciências Agrárias, Recife, v. 5, n. 3, p. 364-369, 2010. 
NOVAIS, R. F.; NEVES, J. C. L.; BARROS, N. F. Ensaio em ambiente controlado. In: OLIVEIRA, A. J.; GARRIDO, W. E.; ARAÚJO, J. D.; LOURENÇO, S. (Ed.). Métodos de pesquisa em fertilidade do solo. Brasília: EMBRAPA-SEA, 1991. p. 189-255.

OLIVEIRA, E. L. Sugestão de adubação e calagem para culturas de interesse econômico no Estado do Paraná. Londrina: Instituto Agronômico do Paraná, IAPAR, 2003. 30 p.

PAFFETTI, D.; DAGUIN, F.; FANCELLI, S.; GNOCCHI, S.; LIPPI, F.; SCOTTI, C.; BAZZICALUPO, $\mathrm{M}$. Influence of plant genotype on the selection of nodulating Sinorhizobium meliloti strains by Medicago sativa. Antonie van Leeuwenhoek, Dordrecht, v. 73, n. 1, p. 3-8, 1998.

PAVAN, M. A.; BLOCH, M. F. M.; ZEMPULSKI, H. C.; MIYAZAWA, M. Manual de análises químicas de solo e controle de qualidade. Londrina: IAPAR, 1992. 40 p. (Circular técnica, 76).

PERES, J. R. R.; SUHET, A. R.; MENDES, I. C.; VARGAS, M. A. T. Efeito da inoculação com rizóbio e da adubação nitrogenada em sete cultivares de feijão em solo de cerrado. Revista Brasileira de Ciência do Solo, Campinas, v. 18, n. 3, p. 415-420, 1994.

PINTO, C. M. F.; VIEIRA, R. F.; VENZON, M.; PAULA JÚNIOR, T. J. de; MATTOS, R. N. Feijãovagem (Phaseolus vulgaris L.) In: PAULA, J. R. T. J.; VENZON, M. (Coord.). 101 culturas; manual de tecnologias agrícolas. Belo Horizonte: EPAMIG, 2007. p. 359-364.

ROMANINI JÚNIOR, A.; ARF, O.; BINOTTI, F. F. S.; SÁ, M. E.; BUZETTI, S.; FERNANDES, F. A. Avaliação da inoculação de rizóbio e adubação nitrogenada no desenvolvimento do feijoeiro, sob sistema plantio direto. Bioscience Journal, Uberlândia, v. 23, n. 4, p. 74-82, 2007.
SANTOS, A. B.; FAGERIA, N. K.; SILVA, O. F.; MELO, N. L. B. Resposta do feijoeiro ao manejo de nitrogênio em várzeas tropicais. Pesquisa Agropecuária Brasileira, Brasília, v. 38, n. 11, p. 1265-1271, 2003.

SESSITSCH, A.; HOWIESON, J. G.; PERRET, X.; ANTONUN, H.; MARTINEZ-ROMERO, E. Advances in Rhizobium research. Critical Reviews in Plant Sciences, Abingdom, v. 21, n. 4, p. 323-378, 2002.

SIQUEIRA, J. O.; MOREIRA, F. M. S.; GRISI, B. M.; HUNGRIA, M.; ARAUJO, R. S. Microrganismos e processos biológicos do solo: perspectiva ambiental. Santo Antônio de Goiás: EMBRAPA-CNPAF; Londrina: EMBRAPA-CNPSo; Brasília: EMBRAPA-SPI, 1994. 142 p.

SMITH, K. P.; GOODMAN, R. M. Host variation for interactions with beneficial plant associated microbes. Annual Reviews of Phytopathology, Palo Alto, v. 37, n. 1, p. 473-491, 1999.

SOARES, A. L. L.; PEREIRA, J. P. A. R.; FERREIRA, P. A. A.; VALE, H. M. M.; LIMA, A. S.; ANDRADE, M. J. B.; MOREIRA, F. M. S. Eficiência agronômica de rizóbios selecionados e diversidade de populações nativas nodulíferas em perdões (MG). Revista Brasileira de Ciência do Solo, Campinas, v. 30, n. 5, p. 795-802, 2006.

STRAliOTTO, R. A importância da inoculação com rizóbio na cultura do feijoeiro. Seropédica: EMBRAPA Agrobiologia/CNPAB, 2002. 6 p.

XAVIER, G. R.; MARTINS, L. M. V.; ASSIS RIBEIRO, J. R. de; RUMJANEK, N. G. Especificidade simbiótica entre rizóbios e acessos de feijão-caupi de diferentes nacionalidades. Revista Caatinga, Mossoró, v. 19, n. 1, p. 25-33, 2006.

YADEGARI, M.; RAHMANI, H. A.; NOORMOHAMMADI, G.; AYNEBAND, A. Plant growth promoting rhizobacteria increase growth, yield and nitrogen fixation in Phaseolus vulgaris. Journal of Plant Nutrition, Philadelphia, v. 33, n. 13, p. 1733-1743, 2010 . 
